\title{
Selection of prey to improve biological parameters of the predator Podisus nigrispinus (Dallas, 1851) (Hemiptera: Pentatomidae) in laboratory conditions
}

\author{
S. A. De Bortoli *, A. M. Vacari ${ }^{a}$, V. L. Laurentis ${ }^{a}$, C. P. De Bortoli ${ }^{a}$, R. F. Santos ${ }^{a}$ and A. K. Otuka ${ }^{a}$ \\ aLaboratório de Biologia e Criação de Insetos - LBCI, Departamento de Fitossanidade, Faculdade de Ciências \\ Agrárias e Veterinárias - FCAV, Universidade Estadual Paulista - UNESP, CEP 14884-900, Jaboticabal, SP, Brazil \\ *e-mail: bortoli@fcav.unesp.br
}

Received: July 14, 2014 - Accepted: January 19, 2015 - Distributed: May 31, 2016

\begin{abstract}
Mass production of predatory stinkbugs in the laboratory is prioritized to release them into the field as part of IPM programs. Therefore, the aim of this study was to identify the best prey for rearing the predator Podisus nigrispinus (Dallas, 1851) (Hemiptera: Pentatomidae) among five different species of insect (three of Lepidoptera, one of Coleoptera, and one of Diptera). Second-instar P. nigrispinus nymphs were conditioned in transparent $1000-\mathrm{mL}$ plastic pots, adults were placed in Petri dishes for mating, and both stages were maintained under controlled conditions $\left(25 \pm 1^{\circ} \mathrm{C}, 12\right.$ hours of photophase, $70 \pm 10 \% \mathrm{RH}$ ). Nymphs and adults of P. nigrispinus consumed more Musca domestica (Linnaeus, 1758) (Diptera: Muscidae) larvae than the other tested prey. The consumption of fly larvae was 1.5 larvae/day/nymph and adults 1.7 larvae/day/adult. However, the number of eggs per female was less when the predator consumed M. domestica larvae (407.8 eggs/female) and most when consumed the Diatraea saccharalis (Fabricius, 1794) (Lepidoptera: Crambidae) larvae (797.7 eggs/female). Furthermore, the percentage of hatched eggs was greater when the predator females consumed $D$. saccharalis larvae $(90.0 \%)$. D. saccharalis larvae is the best prey to rearing $P$. nigrispinus.
\end{abstract}

Keywords: Asopinae, biological control, insect biology, predatory stinkbug.

\section{Seleção de presas para melhorar parâmetros biológicos do predador Podisus nigrispinus (Dallas, 1851) (Hemiptera: Pentatomidae) em condições de laboratório}

\begin{abstract}
Resumo
A produção massal de percevejos predadores no laboratório é priorizada para liberá-los no campo, como parte de programas de MIP. Portanto, o objetivo deste estudo foi identificar a melhor presa para a criação do predador Podisus nigrispinus (Dallas, 1851) (Hemiptera: Pentatomidae) entre cinco espécies diferentes de insetos (três de Lepidoptera, uma de Coleoptera e uma de Diptera). Ninfas de segundo ínstar de P. nigrispinus foram acondicionadas em recipientes plásticos transparentes de $1000 \mathrm{ml}$, adultos foram colocados em placas de Petri para o acasalamento e, ambos os estágios foram mantidos sob condições controladas $\left(25 \pm 1^{\circ} \mathrm{C}\right.$, fotofase de 12 horas e $70 \pm 10 \%$ UR). Ninfas e adultos de P. nigrispinus consumiram mais larvas de Musca domestica (Linnaeus, 1758) (Diptera: Muscidae) do que as outras presas testadas. O consumo de larvas de mosca foi de 1,5 larvas/dia/ninfa e adultos 1,7 larvas/dia/adulto. No entanto, o número de ovos por fêmea foi menor quando o predador consumiu larvas de $M$. domestica (407,8 ovos/fêmea) e maior quando consumiu larvas de Diatraea saccharalis (Fabricius, 1794) (Lepidoptera: Crambidae) (797,7 ovos/fêmea). Além disso, a percentagem de eclosão de ninfas foi maior quando as fêmeas do predador consumiram larvas de D. saccharalis larvas (90,0\%). Larvas de D. saccharalis é a melhor presa para a criação de $P$. nigrispinus.
\end{abstract}

Palavras-chave: Asopinae, controle biológico, biologia de insetos, percevejo predador.

\section{Introduction}

Predatory insects have been used often in developing principles and practices related to integrated pest management (IPM) (Zanuncio et al., 2002, 2014). Pentatomid predators are important to control defoliating caterpillars and other insects (Torres et al., 2006), mainly because they can survive even during prey scarcity (Evangelista Junior et al., 2004). The predator Podisus nigrispinus (Dallas, 1851) (Hemiptera:

Pentatomidae: Asopinae), the most studied species of this family, has been recorded in Argentina, Bolivia, Brazil, Colombia, Costa Rica, Ecuador, Guyana, Panama, Paraguay, Peru, and Surinam (Freitas et al., 2006).

P. nigrispinus presents adequate adaptation to laboratory conditions, with high productivity and a short life cycle, making it a promising species for IPM in Brazil 
(Lemos et al., 2005). Mass rearing P. nigrispinus requires alternative prey (Vacari et al., 2007) due to the difficulty of rearing natural prey in the laboratory, but $P$. nigrispinus performs better with lepidopteran prey (Oliveira et al., 2004a). Mass production P. nigrispinus is a challenging because task this need food supply at a maximum 4 days interval, which requires large and expensive prey colonies (De Clercq et al., 1998).

In Minas Gerais State, Brazil, forest companies, such as "CAF Florestal Ltda" (Belo Horizonte), "V\&M Florestal Ltda" (Paraopeba), and "Refloralje" (Montes Claros), have established laboratories to produce Asopinae predators. Mass production and release $P$. nigrispinus are based on the rotation cycle of eucalyptus forests (ca. 6-7 years) and forecasting outbreak pest periods, which allows using inoculative releases of this predator in more susceptible areas to insect outbreaks (Zanuncio et al., 2002; Torres et al., 2006; Vacari and De Bortoli, 2010).

Mass productions of predatory stinkbugs in the laboratory are prioritized to release them into the field as part of IPM programs (De Bortoli et al., 2011). Therefore, the aim of this study was to identify a prey to provide the best conditions to mass rearing $P$. nigrispinus in the laboratory.

\section{Material and Methods}

The prey used were larvae of Anticarsia gemmatalis Hübner, 1818 (Lepidoptera: Noctuidae) and Spodoptera frugiperda (J.E. Smith, 1797) (Lepidoptera: Noctuidae) obtained from the mass rearing at DuPont Agrosciences (Paulinia, São Paulo, Brazil); larvae of Diatraea saccharalis (Fabricius, 1794) (Lepidoptera: Crambidae) from the mass rearing at Usina Santa Adelia (Jaboticabal, São Paulo); larvae of Tenebrio molitor Linnaeus, 1758 (Coleoptera: Tenebrionidae) from the mass rearing at LBRI, FCAV/Unesp; and larvae of Musca domestica Linnaeus, 1758 (Diptera: Muscidae) from the mass rearing of the Laboratory of Frog Culture, CAUNESP, Unesp/Jaboticabal. P. nigrispinus nymphs were obtained from mass rearing of the LBRI, Department of Plant Protection, FCAV/Unesp, Campus de Jaboticabal.
One hundred second-instar nymphs of $P$. nigrispinus were used per treatment. They were placed in 4 transparent 1000-mL plastic containers (25 nymphs per container), and larvae of each species of prey provided ad libitum to them. Insects were maintained at $25 \pm 1{ }^{\circ} \mathrm{C}, 70 \pm 10 \%$ relative humidity, and 12-hours photophase. Water was provided in a tube fixed on the lid of the container, with the tip turned inwards with cotton pad placed in the tube to allow a supply of water by capillary action. Evaluations were performed daily to determine the following biological parameters for nymphs: the length of the nymphal period, nymphal survival, consumption of prey for nymph, and the weight of the fifth-instar nymphs were measured.

After emergence, the adults of $P$. nigrispinus were isolated in pairs ( 1 female and 1 male) and transferred to Petri dishes $(9 \mathrm{~cm} \times 1.5 \mathrm{~cm})$ where were also placed the prey according to the treatment and water was supplied via a cotton swab placed in the lid. All eggs were collected, counted, and placed in Petri dishes $(6 \mathrm{~cm} \times 2 \mathrm{~cm})$ until they hatched. Weights of recently emerged males and females, adult lifespan, prey consumed, number of eggs per female, number of eggs per clutch, and durations of the pre-oviposition, oviposition, and post-oviposition periods were determined. The egg incubation period and their viability were also measured.

The design of experiment was completely randomized. Data were submitted to analysis of variance (ANOVA) and, when significant, the means were compared using the Tukey test $(\mathrm{P} \leq 0.01)$.

\section{Results and Discussion}

P. nigrispinus nymphs consumed all species of caterpillars (S. frugiperda, A. gemmatalis, and D. saccharalis) (Table 1), but they consumed more larvae of $M$. domestica than any other prey species, probably because of the body size of the individuals to be smaller, while T. molitor larvae were the least consumed prey, probably due the exoskeleton of its larvae is well sclerotized, making them less preferable for pentatomid predators (Silva et al., 2012). The results obtained corroborate the observations of De Clercq et al. (1998), which P. nigrispinus shows natural preference

Table 1. Biological parameters of nymphal stage of Podisus nigrispinus fed on larvae of Spodoptera frugiperda, Anticarsia gemmatalis, Diatraea saccharalis, Tenebrio molitor, and Musca domestica larvae in laboratory.

\begin{tabular}{cccc}
\hline Treatments & $\begin{array}{c}\text { Consumption of prey per nymph } \\
\text { (larvae/day/nymph) }\end{array}$ & $\begin{array}{c}\text { Nymphal period } \\
\text { (days) }\end{array}$ & $\begin{array}{c}\text { Nymphal } \\
\text { viability } \\
\text { (\%) }\end{array}$ \\
\hline S. frugiperda & $1.11 \pm 0.01 \mathrm{bc}^{1}(1.10-1.12)$ & $23.31 \pm 2.99 \mathrm{a}(20.31-26.30)$ & 60 \\
A. gemmatalis & $1.12 \pm 0.02 \mathrm{~b}(1.10-1.13)$ & $23.08 \pm 2.79 \mathrm{a}(20.29-25.87)$ & 55 \\
D. saccharalis & $1.11 \pm 0.02 \mathrm{bc}(1.09-1.13)$ & $21.14 \pm 2.13 \mathrm{~b}(19.01-23.27)$ & 76 \\
T. molitor & $1.06 \pm 0.02 \mathrm{c}(1.04-1.09)$ & $19.84 \pm 1.73 \mathrm{~b}(18.10-21.57)$ & 61 \\
M. domestica & $1.46 \pm 0.08 \mathrm{a}(1.38-1.54)$ & $19.50 \pm 0.37 \mathrm{~b}(19.13-19.87)$ & 80 \\
F & $84.03^{* *}$ & $14.18^{* *}$ & \\
CV $(\%)$ & 11.70 & 20.95 & \\
\hline
\end{tabular}

${ }^{1}$ Means \pm confidence interval followed by the same letter in the same column do not differ according to a Tukey test at the $1 \%$ level of probability. **Indicates a significant difference $(\mathrm{P}<0.01)$. 
to predation of soft tegument and slow movement prey, particularly caterpillars and Chrysomelidae and Coccinellidae larvae that feed on foliage, and they show that the type of prey offered may affect the performance of predatory stinkbugs, as pointed out by De Clercq et al. (1998) and Lemos et al. (2003).

Saavedra et al. (1997) gave third-instar A. gemmatalis larvae to $P$. nigrispinus and reported similar consumption results to those of this study. Vivan et al. (2002) found that $P$. nigrispinus nymphs consumed 2.3 to 2.5 larvae of Tuta absoluta (Meyrick, 1917) (Lepidoptera: Gelechiidae) per day, which differs to the results obtained with other lepidopteran larvae in the present study. It is possible that this highest consumption may be due to the smaller body size of T. absoluta larvae.

The nymphal period of $P$. nigrispinus varied with the type of prey (Table 1). It was lower when predators were fed on larvae of $D$. saccharalis, T. molitor, and M. domestica, than fed on caterpillars of $S$. frugiperda and A. gemmatalis.

Peluzio (2008) reported similar nymphal periods when $P$. nigrispinus was fed on caterpillars of $A$. gemmatalis (25.20 days). Oliveira et al. (2004a) reported nymphal periods ranging from 19.81 to 20.39 days when P. nigrispinus was fed on caterpillars of $S$. frugiperda and from 21.61 to 22.51 days when this predator $P$. nigrispinus was fed on larvae of T. molitor. Lemos et al. (2003) reported a mean development time of 4.05 days for each instar of this pentatomid when fed on T. molitor larvae. Lacerda et al. (2004) recorded a development time of 19.03 days for P. nigrispinus fed on M. domestica larvae, which is similar to the results observed in the present study. According to Strohmeyer et al. (1998), in addition to prey type, the quality of the diet of the prey affects the growth rate of some predators, including the pentatomids which as Podisus maculiventris (Say, 1832) (Heteroptera: Pentatomidae).

Although various factors affect the development of bugs in the subfamily Asopinae (Zanuncio et al., 2001, 2008; Lemos et al., 2003, 2005; Lacerda et al. 2004), several researchers have reported $P$. nigrispinus nymphal stage durations of approximately 20 days when they are reared on different prey (Zanuncio et al., 2001), suggesting that the prey evaluated in the present study does not dramatically change the duration of the nymphal stage, as pointed out by Oliveira et al. (2004a).

Viability of the second-instar nymph of $P$. nigrispinus fed on different prey is reported in Table 1. According to Lemos et al. (2005), larvae attacked by predators exhibit different responses, for example, they may escape and/or attack with bites or regurgitation of compounds during fights, causing injury or even the death of the predators. The low viability of $P$. nigrispinus fed on $S$. frugiperda and A. gemmatalis larvae is probably due to the stronger defense reactions of these prey when attacked compared to T. molitor and M. domestica (Silva et al., 2012). Sudden movements of the body and head by caterpillars of $S$. frugiperda and A. gemmatalis during attacks by $P$. nigrispinus resulted in the death of nymphs.
The nymphal viability observed in this study was similar to that reported by Oliveira et al. (2004a) for $S$. frugiperda (64\%) and T. molitor (68\%), and by Zanuncio et al. (2001) for $M$. domestica (73\%). However, our results differed from those of Lemos et al. (2003), in which larvae of $M$. domestica were alternated with $T$. molitor pupae, which resulted in a nymphal viability of $51.84 \%$.

Vacari et al. (2007) reported a nymphal viability of $89 \%$ for $P$. nigrispinus when they were fed on larvae of $D$. saccharalis, which differs from our results. The highest viability $(98.96 \%)$ recorded for $P$. nigrispinus occurred when feeding on larvae of Alabama argillacea Hübner, 1818 (Lepidoptera: Noctuidae) (Lemos et al., 2003). Nymphal viability was lower when $P$. nigrispinus was fed on $M$. domestica alternating with T. molitor (51.84\%) (Lemos et al., 2003) and $S$. frugiperda (64\%) (Oliveira et al., 2004a). Some of these results are similar to those obtained in this study and suggest that $P$. nigrispinus is adapted to different prey. Some results may vary because of the abiotic and biotic experimental conditions were different. For example, in some studies, predators are given supplementary food in addition to the different prey species.

The weight of the fifth-stage $P$. nigrispinus nymphs was higher when they were fed on $D$. saccharalis caterpillars (Table 2), possibly because this prey had higher nutritional quality (Oliveira et al., 2004a). The weight these nymphs were similar when fed on the other prey evaluated.

Our data differ from those of Vacari et al. (2007), who found that the weight of the fifth-stage P. nigrispinus nymphs fed on larvae of $D$. saccharalis was $20.40 \mathrm{mg}$, and from those of Oliveira et al. (2004b), who found that the weight of these nymphs fed on S. frugiperda and T. molitor were 26.26 and $27.11 \mathrm{mg}$, respectively. According to Zanuncio et al. (2001), greater nymphal weight is due to the accumulation of biomass required for the reproductive stadium and early growth of the reproductive system in females begins in the fifth instar.

Peluzio (2008) reported a difference between the weights of fifth-instar nymphs of $P$. nigrispinus fed on A. gemmatalis larvae (ranging from 25.38 to $26.66 \mathrm{mg}$ ) and they fed on T. molitor larvae $(35.30 \mathrm{mg})$. Differences in nymphal weights may be due to several factors, such as photoperiod (14 hours), locality in which the experiment was performed (Viçosa), and the ingredients used in making the diet offered as food for larvae (soybean leaves were used instead of an artificial diet).

Females and males of $P$. nigrispinus fed on all species of caterpillars, and larvae of T. molitor and M. domestica (Table 2). The weight of $P$. nigrispinus females was highest when they were fed on $D$. saccharalis larvae, but were similar to females fed on T. molitor and M. domestica larvae (Table 2). The weight of $P$. nigrispinus females was lowest when they were fed on the other two caterpillars species tested. The weight of $P$. nigrispinus males fed on $S$. frugiperda larvae were not significantly different from that of males fed on other types of prey; however, those fed on D. saccharalis, A. gemmatalis, and M. domestica larvae differed significantly from those fed on $T$. molitor larvae. 
The lower weight of $P$. nigrispinus females fed on caterpillars of $A$. gemmatalis and $S$. frugiperda may be due to the lower quality of these prey compared with T. molitor, M. domestica, and D. saccharalis. Weights of adult $P$. nigrispinus may influence their reproductive success. This is particularly evident in the interaction between female weight and fecundity (Oliveira et al., 2005 ) because the weight of predatory stinkbugs and their reproductive potential are correlated (Zanuncio et al., 2002; Legaspi and Legaspi Junior et al., 2005).

The results of this study differ from those of Oliveira et al. (2004b), who reported that the average weights of $P$. nigrispinus males fed on larvae of $S$. frugiperda and T. molitor were 40.81 and $36.54 \mathrm{mg}$, respectively, probably because the prey, despite being the same species, may have differed nutritionally depending on their diet (Bavaresco et al., 2004).

Peluzio (2008) reported that adult male adult of $P$. nigrispinus predators weighed more when fed on T. molitor than when fed on A. gemmatalis. This differed from the results obtained in this study, which may be due to the predatory stinkbug having been fed on pupae of T. molitor instead of larvae.

Adults consumed more $M$. domestica larvae than any other prey species, probably because they were the smallest prey. Adults consumed similar amounts of all other prey (Table 3). In the field, the rate of predation of Podisus Herrich-schaeffer, 1851 on several prey species varies from 0.32 to 2.46 attacks/female/day (Oliveira et al., 2008; Pires et al., 2009; Vivan et al., 2002) and is mainly affected by the size of the larva, plant type, and climatic conditions. According to Vivan et al. (2002), adult P. nigrispinus consumed an average of $50.8 \mathrm{~T}$. absoluta larvae, which are smaller than $M$. domestica larvae, P. nigrispinus adults consumed 9.1 Plutella xylostella (Linnaeus, 1758) (Lepidoptera: Plutellidae) larvae daily and up to 346.0 during their adulthood (Vacari et al., 2013). According to Oliveira et al. (2008), P. nigrispinus adults consumed 0.93 to $1.23 \mathrm{~A}$. gemmatalis larvae/day. In addition, according to Oliveira et al. (2008), adult $P$. nigrispinus may consume 1.3 third-instar $A$. gemmatalis larvae daily under laboratory conditions.

The longevity of males was similar among those fed on A. gemmatalis, D. saccharalis, and M. domestica, and also similar to the longevity of those fed on $S$. frugiperda and T. molitor (Table 3). However, the longevity of males fed on $S$. frugiperda was significantly different from males fed on T. molitor. Adult males fed on T. molitor larvae and $S$. frugiperda caterpillars had the longest and shortest lifespans, respectively.

There were no differences in the longevity of females fed on all species of the caterpillars evaluated, or M. domestica

Table 2. Biological parameters of fifth-stage Podisus nigrispinus nymphs and of recently emerged adults males and females fed on larvae of Spodoptera frugiperda, Anticarsia gemmatalis, Diatraea saccharalis, Tenebrio molitor, and Musca domestica larvae in laboratory.

\begin{tabular}{cccc}
\hline Treatments & $\begin{array}{c}\text { Weight of the fifth stage } \\
\text { nymphs }(\mathbf{m g})\end{array}$ & Weight of females (mg) & Weight of males (mg) \\
\hline S. frugiperda & $35.23 \pm 3.76 \mathrm{~b}^{1}(31.47-38.99)$ & $37.58 \pm 2.66 \mathrm{~b}(34.92-40.24)$ & $30.34 \pm 2.90 \mathrm{ab}(27.44-33.24)$ \\
A. gemmatalis & $36.89 \pm 2.79 \mathrm{~b}(34.10-39.68)$ & $36.45 \pm 2.27 \mathrm{~b}(34.18-38.72)$ & $36.89 \pm 2.79 \mathrm{a}(34.10-39.68)$ \\
D. saccharalis & $44.03 \pm 2.19 \mathrm{a}(41.84-46.22)$ & $44.03 \pm 2.62 \mathrm{a}(41.41-46.65)$ & $34.65 \pm 3.34 \mathrm{a}(31.31-37.99)$ \\
T. molitor & $36.13 \pm 2.40 \mathrm{~b}(33.73-38.53)$ & $40.78 \pm 3.60 \mathrm{ab}(337.18-44.38)$ & $27.73 \pm 1.93 \mathrm{~b}(25.77-29.69)$ \\
M. domestica & $34.07 \pm 2.50 \mathrm{~b}(31.56-36.57)$ & $40.78 \pm 2.91 \mathrm{ab}(37.87-43.69)$ & $36.20 \pm 2.33 \mathrm{a}(33.87-38.52)$ \\
$\mathrm{F}$ & $13.37 * *$ & $4.43 * *$ & $7.48 * *$ \\
$\mathrm{CV}(\%)$ & 21.60 & 19.68 & 19.62 \\
\hline
\end{tabular}

${ }^{1}$ Means \pm confidence interval followed by the same letter in the same column do not differ according to a Tukey test at the $1 \%$ level of probability. $* *$ Indicates a significant difference $(\mathrm{P}<0.01)$.

Table 3. Biological parameters of male and female of Podisus nigrispinus fed on larvae of Spodoptera frugiperda, Anticarsia gemmatalis, Diatraea saccharalis, Tenebrio molitor, and Musca domestica larvae in laboratory.

\begin{tabular}{cccc}
\hline Treatments & $\begin{array}{c}\text { Consumption per adult } \\
\text { (larvae/day/adult) }\end{array}$ & Longevity of males (days) & Longevity of females (days) \\
\hline S. frugiperda & $1.25 \pm 0.05 \mathrm{~b}^{1}(1.20-1.30)$ & $19.91 \pm 0.55 \mathrm{~b}(19.36-20.46)$ & $22.41 \pm 0.90 \mathrm{a}(21.51-23.31)$ \\
A. gemmatalis & $1.24 \pm 0.05 \mathrm{~b}(1.19-1.29)$ & $20.58 \pm 1.96 \mathrm{ab}(22.62-18.53)$ & $20.42 \pm 1.79 \mathrm{ab}(18.64-22.21)$ \\
D. saccharalis & $1.25 \pm 0.04 \mathrm{~b}(1.21-1.30)$ & $20.90 \pm 1.15 \mathrm{ab}(19.75-22.05)$ & $23.13 \pm 1.36 \mathrm{a}(21.77-24.49)$ \\
T. molitor & $1.20 \pm 0.05 \mathrm{~b}(1.04-1.25)$ & $22.91 \pm 1.05 \mathrm{a}(21.85-23.96)$ & $14.48 \pm 1.30 \mathrm{~b}(16.18-18.78)$ \\
M. domestica & $1.66 \pm 0.14 \mathrm{a}(1.52-1.80)$ & $20.65 \pm 1.39 \mathrm{ab}(19.26-22.04)$ & $22.95 \pm 1.46 \mathrm{a}(21.49-24.41)$ \\
$\mathrm{F}$ & $25.82 * *$ & $2.13 * *$ & $3.74 * *$ \\
$\mathrm{CV}(\%)$ & 16.84 & 18.50 & 29.78 \\
\hline
\end{tabular}

${ }^{1}$ Means \pm confidence interval followed by the same letter in the same column do not differ according to a Tukey test at the $1 \%$ level of probability. $* *$ Indicates a significant difference $(\mathrm{P}<0.01)$. 
(Table 3). Females fed on T. molitor larvae had shorter lives. This may be related to the lower consumption of this prey by adults because of their hardened integument (Silva et al., 2012), which suggests that T. molitor was not sufficient for females to acquire sufficient energy to reproduce and survive.

Our results differed from those obtained by Oliveira et al. (2004a) who found no difference in the longevity of P. nigrispinus males fed on T. molitor or S. frugiperda larvae. Lacerda et al. (2004) obtained similar results when P. nigrispinus were fed on T. molitor larvae (23.46 days) and $M$. domestica larvae (19.20 days). The longevity of $P$. nigrispinus males fed on larvae of $D$. saccharalis was 14.87 days for Vacari et al. (2007), which differed from the results of this study. Zanuncio et al. (2008) reported longevities of 27.4 and 39.6 days when P. nigrispinus was fed on T. molitor alone and T. molitor with Eucalyptus grandis, respectively.

Vacari et al. (2007) observed that the lifespan of female $P$. nigrispinus fed on $D$. saccharalis larvae was 17.61 days, unlike the results obtained in this study, and much lower than the results of Oliveira et al. (2004a), when they fed $P$. nigrispinus with $T$. molitor larvae to $P$. nigrispinus. The lifespans were also lower than when female $P$. nigrispinus were fed on larvae of Thyrinteina arnobia (Stoll, 1782) (Lepidoptera: Geometridae) larvae (35.54 days) (Oliveira et al., 2011) and larvae of $M$. domestica (20.3 days) (Lacerda et al., 2004).

Lemos et al. (2003) and Oliveira et al. (2004a; 2011) also observed that females live longer than males (29.3 days compared to 28.1 days when fed on larvae of Bombyx mori (Linnaues, 1758) (Lepidoptera: Bombycidae) and M. domestica alternately, 67.2 days compared to 49.5 days when fed on T. molitor larvae). However, females only lived 35.54 days compared to 43.08 days when fed on T. arnobia caterpillars. The results of $T$. molitor larvae as prey reported by Oliveira et al. (2004a) differ from the data obtained in the present study, where females had lower longevity than males.

Females fed different prey did not show any difference in the duration of the pre-oviposition or post-oviposition periods (Table 4). Data for the length of the pre-ovipositon and post-oviposition periods obtained in this study are similar to those reported by Oliveira et al. (2004a). The oviposition period was longer when females were fed on $M$. domestica larvae and was shorter when they were fed on T. molitor larvae (Table 4). These results suggest that $M$. domestica is nutritionally adequate for P. nigrispinus. The combination of $S$. frugiperda and T. molitor larvae may also be nutritionally adequate (Oliveira et al., 2004b).

According to Peluzio (2008), the pre-oviposition period of $P$. nigrispinus females is shorter when the prey is $T$. molitor pupae, and longer when it is A. gemmatalis larvae. Vacari et al. (2013) reported a pre-ovipositon period of 5.7 days when fed on fourth-instar P. xylostella larvae and a post-oviposition period of 3.0 days. The pre-ovipositon period of Podisus distinctus (Stäl, 1860) (Hemiptera: Pentatomidae) was shorter when they were fed on B. mori larvae, which is a higher-quality prey from which the female predator may quickly obtain nutrients for egg production (Lemos et al., 2003, 2005).

Lacerda et al. (2004) reported shorter periods of oviposition and post-oviposition when $P$. distinctus was fed on $B$. mori larvae, which indicates that this prey is of high quality. This resulted in high reproductive capacity, which is similar to that reported for P. nigrispinus females fed fourth-stage $P$. xylostella larvae was reported by Vacari et al. (2013), while Peluzio (2008) reported a 16.58 days ovipositon period when predators were fed on A. gemmatalis larvae and 7.33 days when they were fed on T. molitor larvae. Of the studied prey, T. molitor has the lowest nutritional quality.

Females of $P$. nigrispinus fed on D. saccharalis larvae produced more eggs per female than when fed other prey (Table 5). They produced 469 more eggs on average than when fed on T. molitor, the prey resulted in the lowest number of eggs per female.

When fed on $S$. frugiperda, females $P$. nigrispinus had an average of 14.89 egg masses, each with 30.06 eggs; when fed on T. molitor larvae, they had an average of 17 egg masses, each with 19.06 eggs (Oliveira et al., 2004a); and when gave T. absoluta larvae as a prey, they had an average of 15.7 eggs per mass (Vivan et al., 2002).

Table 4. Reproductive parameters of Podisus nigrispinus females fed on larvae of Spodoptera frugiperda, Anticarsia gemmatalis, Diatraea saccharalis, Tenebrio molitor, and Musca domestica larvae in laboratory.

\begin{tabular}{cccc}
\hline Treatments & Pre-oviposition (days) & $\begin{array}{c}\text { Oviposition } \\
\text { (days) }\end{array}$ & Post-oviposition (days) \\
\hline S. frugiperda & $4.39 \pm 0.17 \mathrm{a}^{1}(4.22-4.56)$ & $11.52 \pm 1.79 \mathrm{bc}(9.73-13.30)$ & $6.21 \pm 1.54 \mathrm{a}(4.67-7.75)$ \\
A. gemmatalis & $4.58 \pm 0.17 \mathrm{a}(4.41-4.75)$ & $16.27 \pm 2.83 \mathrm{~b}(13.44-19.11)$ & $7.76 \pm 2.26 \mathrm{a}(5.50-10.02)$ \\
D. saccharalis & $4.45 \pm 0.16 \mathrm{a}(4.29-4.62)$ & $15.88 \pm 3.39 \mathrm{~b}(12.49-19.27)$ & $7.82 \pm 3.72 \mathrm{a}(4.10-11.54)$ \\
T. molitor & $4.70 \pm 0.19 \mathrm{a}(4.51-4.89)$ & $7.30 \pm 1.61 \mathrm{c}(5.69-8.92)$ & $5.09 \pm 1.48 \mathrm{a}(3.61-6.57)$ \\
M. domestica & $4.64 \pm 0.15 \mathrm{a}(4.49-4.79)$ & $22.45 \pm 2.46 \mathrm{a}(19.99-24.92)$ & $9.85 \pm 2.63 \mathrm{a}(7.22-12.48)$ \\
F & $1.96^{\mathrm{NS}}$ & $15.89^{* *}$ & $1.89^{\mathrm{NS}}$ \\
$\mathrm{CV}(\%)$ & 10.89 & 29.29 & 10.34 \\
\hline
\end{tabular}

${ }^{1}$ Means \pm confidence interval followed by the same letter in the same column do not differ according to a Tukey test at the $1 \%$ level of probability. ${ }^{* *}$ Indicates a significant difference $(\mathrm{P}<0.01),{ }^{\mathrm{NS}}$ no significant diference. 
The differences in the number of eggs and clusters are probably due to the abiotic environmental conditions in which the insects were obtained. According to Oliveira et al. (2004a), when P. nigrispinus females were fed on $S$. frugiperda and T. molitor, their eggs were concentrated in a smaller number of egg masses, which facilitates the manipulation of rearing in the laboratory, as observed in the present study with $P$. nigrispinus fed on $S$. frugiperda and T. molitor.

The mean number of eggs per female of $P$. nigrispinus fed on D. saccharalis (797 eggs) (Table 5) was higher than the values found by Oliveira et al. (2002), who reared $P$. nigrispinus with $T$. molitor pupae and tomato plants. When the predator fed on a combination of $T$. molitor pupae and $M$. domestica larvae, the number of eggs was lower than in our study (Zanuncio et al., 2001). However, the values reported by these authors were similar to those of this study when $P$. nigrispinus was fed on $S$. frugiperda and $A$. gemmatalis larvae. The combination of prey may supplement the nutritional requirements of $P$. nigrispinus, resulting in a greater number of eggs per female. Thus, P. nigrispinus females fed on the $D$. saccharalis, $S$. frugiperda, and $A$. gemmatalis larvae, which have better nutritional quality, may produce more eggs (Oliveira et al., 2004a).

The number of eggs per female of $P$. nigrispinus fed on $S$. frugiperda, A. gemmatalis, or T. molitor larvae was similar to that reported by Oliveira et al. (2004a). The results obtained for P. nigrispinus females fed on M. domestica larvae differed from those obtained by Espindula et al. (2006) (296.66 eggs), perhaps because the researchers fed the prey adult plants, which did not occur in this study.

The incubation periods of the eggs of $P$. nigrispinus fed on S. frugiperda, A. gemmatalis, T. molitor, and $M$. domestica larvae were similar to each other, but differed from the incubation period of those fed on $D$. saccharalis larvae (Table 6). The shorter incubation period found with D. saccharalis is within the ranges reported by several authors (Freitas et al., 2006; Vacari et al., 2007; Peluzio, 2008).

The eggs produced by $P$. nigrispinus females fed on $D$. saccharalis and $S$. frugiperda larvae had higher egg viability, while females fed T. molitor and $M$. domestica had lower egg viability (Table 6). In addition to the higher average fecundity of females fed on larvae of $D$. saccharalis, egg viability was also higher. Females fed on S. frugiperda, A. gemmatalis, and $D$. saccharalis larvae produced higher numbers of eggs and had greater longevity when compared to females fed $T$. molitor (Table 6).

Peluzio (2008) reported that the incubation periods of P. nigrispinus fed on A. gemmatalis and T. molitor larvae were 3.95 and 4.59 days, respectively. Freitas et al. (2006) observed no difference between incubation periods predators were fed on larvae of T. molitor (4.71 to 4.75 days) or A. gemmatalis (4.75 to 4.79 days). The incubation period was 4.9 days for P. nigrispinus females fed on larvae of P. xylostella (Vacari et al., 2013).

Table 5. Reproductive parameters of Podisus nigrispinus females fed on larvae of Spodoptera frugiperda, Anticarsia gemmatalis, Diatraea saccharalis, Tenebrio molitor, and Musca domestica larvae in laboratory.

\begin{tabular}{cccc}
\hline Treatments & Number of egg mass/female & Number of eggs/mass & Number of eggs/female \\
\hline S. frugiperda & $8.70 \pm 1.72 \mathrm{bc}^{1}(6.98-10.42)$ & $50.81 \pm 7.18 \mathrm{a}(43.63-57.99)$ & $442.03 \pm 4.43 \mathrm{~b}(437.60-446.46)$ \\
A. gemmatalis & $12.73 \pm 1.49 \mathrm{~b}(11.24-14.22)$ & $34.69 \pm 6.98 \mathrm{~b}(27.71-41.67)$ & $441.60 \pm 31.86 \mathrm{~b}(409.74-473.46)$ \\
D. saccharalis & $15.66 \pm 2.62 \mathrm{~b}(13.04-18.28)$ & $50.94 \pm 6.88 \mathrm{a}(44.06-57.82)$ & $797.71 \pm 19.14 \mathrm{a}(778.57-816.86)$ \\
T. molitor & $7.56 \pm 1.80 \mathrm{c}(5.76-9.36)$ & $43.43 \pm 7.02 \mathrm{ab}(36.41-50.45)$ & $328.57 \pm 20.52 \mathrm{~d}(308.05-349.08)$ \\
M. domestica & $19.80 \pm 1.89 \mathrm{a}(17.91-21.69)$ & $20.59 \pm 2.95 \mathrm{c}(17.64-23.54)$ & $407.76 \pm 12.09 \mathrm{c}(395.66-419.85)$ \\
F & $15.38^{* *}$ & $20.90^{* *}$ & $544.53^{* *}$ \\
CV $(\%)$ & 28.27 & 12.83 & 9.33 \\
\hline
\end{tabular}

${ }^{1}$ Means \pm confidence interval followed by the same letter in the same column do not differ according to a Tukey test at the $1 \%$ level of probability. $* *$ Indicates a significant difference $(\mathrm{P}<0.01)$.

Table 6. Parameters of egg stage of Podisus nigrispinus females fed on larvae of Spodoptera frugiperda, Anticarsia gemmatalis, Diatraea saccharalis, Tenebrio molitor, and Musca domestica larvae in laboratory.

\begin{tabular}{ccc}
\hline Treatments & Incubation period (days) & Egg viability (\%) \\
\hline S. frugiperda & $5.46 \pm 0.37 \mathrm{a}^{1}(5.08-5.83)$ & $86.00 \pm 2.00 \mathrm{ab}(84.00-88.00)$ \\
A. gemmatalis & $5.07 \pm 0.38 \mathrm{ab}(4.69-5.44)$ & $81.00 \pm 2.00 \mathrm{~b}(79.00-83.00)$ \\
D. saccharalis & $4.34 \pm 0.38 \mathrm{~b}(3.95-4.72)$ & $90.00 \pm 4.00 \mathrm{a}(86.00-94.00)$ \\
T. molitor & $5.38 \pm 0.72 \mathrm{ab}(4.66-6.10)$ & $70.00 \pm 2.00 \mathrm{c}(68.00-72.00)$ \\
M. domestica & $5.19 \pm 0.58 \mathrm{ab}(4.61-5.77)$ & $73.00 \pm 2.00 \mathrm{c}(71.00-75.00)$ \\
F & $3.36^{* *}$ & $47.75^{* *}$ \\
$\mathrm{CV}(\%)$ & 28.64 & 4.78 \\
\hline
\end{tabular}

${ }^{1}$ Means \pm confidence interval, followed by the same letter in the same column do not differ by Tukey test at the $1 \%$ level of probability. ${ }^{* *}$ Indicates a significant difference $(\mathrm{P}<0.01)$. 
Other studies have shown that the viability of P. nigrispinus eggs was $43.27 \%$ when they were fed on immobilized $M$. domestica larvae, $41.55 \%$ when they were fed on free $M$. domestica larvae, $58.54 \%$ when they were fed on T. molitor, $65.09 \%$ when they were fed on Heliothis virescens (Fabricius, 1777) (Lepidoptera: Notctuidae), and $75 \%$ when they were fed on T. molitor and M. domestica alternately (Zanuncio et al., 2001; Pires et al., 2009; Espindula et al., 2010). Variations in the egg viability of $P$. nigrispinus may be due to the fact that insects are not reared in isolation; therefore, there is no way to control the number and frequency of copulations (Torres et al., 1997).

The adult weight of $P$. nigrispinus may also indicate the reproductive success of the species, in particular the interaction between weight and female fertility, as suggested by Evans (1982). This suggests that the females fed on caterpillars of $D$. saccharalis could produce more eggs because they had the highest weights. Thus, the best prey among the others prey evaluated to improve the development and reproduction of the predator $P$. nigrispinus in a mass rearing is $D$. saccharalis larvae, which suggest that this prey is better to be used mass rearing of this predator to be applied in IPM, mainly by the augmentative biological control strategy.

\section{Acknowledgements}

We are thankful to the Conselho Nacional de Desenvolvimento Científico e Tecnológico-CNPq for the scholarships.

\section{References}

BAVARESCO, A., GARCIA, M.S., GRÜTZMACHER, A.D., RINGENBERG, R. and FORESTI, J., 2004. Adequação de uma dieta artificial para a criação de Spodoptera cosmioides (Walk.) (Lepidoptera: Noctuidae) em laboratório. Neotropical Entomology, vol. 33, no. 2, pp. 155-161. http://dx.doi.org/10.1590/S1519566X2004000200005.

DE BORTOLI, S.A., OTUKA, A.K., VACARI, A.M., MARTINS, M.I.E.G. and VOLPE, H.X.L., 2011. Comparative biology and production costs of Podisus nigrispinus (Hemiptera: Pentatomidae) when fed different types of prey. Biological Control, vol. 58, no. 2, pp. 127-132. http://dx.doi.org/10.1016/j.biocontrol.2011.04.011.

DE CLERCQ, P., MERLEVEDE, F., MESTDAGH, I., VANDENDURPEL, K., MOHAGHEGH, J. and DEGHEELE, D., 1998. Predation on the tomato looper Chrysodeixis chalcites (Esper) (Lepidoptera: Noctuidae) by Podisus maculiventris (Say) and Podisus nigrispinus (Dallas) (Heteroptera: Pentatomidae). Journal of Applied Entomology, vol. 2, no. 1-5, pp. 93-98. http:// dx.doi.org/10.1111/j.1439-0418.1998.tb01468.x.

ESPINDULA, M.C., OLIVEIRA, H.N., CAMPANHARO, M., PASTORI, P.L. and MAGEVSKI, G.C., 2006. Influência da massa corporal sobre características reprodutivas e longevidade de fềmeas de Podisus nigrispinus (Dallas) (Heteroptera: Pentatomidae). Idesia, vol. 24, no. 3, pp. 19-25.

ESPINDULA, M.C., ZANUNCIO, J.C., ANDRADE, G.S., PASTORI, P.L., OLIVEIRA, H.N. and MAGEVSKI, G.C., 2010. Desenvolvimento e reprodução de Podisus nigrispinus (Dallas) (Heteroptera: Pentatomidae) alimentado com lagartas de Heliothis virescens (Lepidoptera: Noctuidae). Idesia, vol. 28, no. 3, pp. 17-24. http://dx.doi.org/10.4067/S0718-34292010000300003.

EVANGELISTA JUNIOR, W.S., GONDIM JUNIOR, M.G.C., TORRES, J.B. and MARQUES, E.J., 2004. Fitofagia de Podisus nigrispinus em algodoeiro e plantas daninhas. Pesquisa Agropecuaria Brasileira, vol. 39, no. 5, pp. 413-420. http://dx.doi.org/10.1590/ S0100-204X2004000500002.

EVANS, E.W., 1982. Consequences of body size for fecundity in the predatory stinkbug, P. maculaventris (Heteroptera: Pentatomidae). Annals of the Entomological Society of America, vol. 75, no. 4, pp. 418-420. http://dx.doi.org/10.1093/aesa/75.4.418.

FREITAS, S.P.C., EVANGELISTA JÚNIOR, W.S., ZANUNCIO, J.C. and SERRÃO, J.E., 2006. Development, survival and reproduction of Podisus nigrispinus (Dallas, 1851) (Heteroptera: Pentatomidae) with salt and amino acids solution supplementary diet. Brazilian Archives of Biology and Technology, vol. 49, no. 3, pp. 449-455. http://dx.doi.org/10.1590/S1516-89132006000400013.

LACERDA, M.C., FERREIRA, A.M.R.M., ZANUNCIO, T.V., ZANUNCIO, J.C., BERNARDINO, A.S. and ESPINDULA, M.C., 2004. Development and reproduction of Podisus distinctus (Heteroptera: Pentatomidae) fed on larvae of Bombyx mori (Lepidoptera: Bombycidae). Brazilian Journal of Biology $=$ Revista Brasileira de Biologia, vol. 64, no. 2, pp. 237-242. http:// dx.doi.org/10.1590/S1519-69842004000200008. PMid:15462296.

LEGASPI, J.C. and LEGASPI JUNIOR, B.C., 2005. Body weigths and egg loads in field-collected Podisus maculaventris (Heteroptera: Pentatomidae). The Florida Entomologist, vol. 88, no. 1, pp. 38-42. http://dx.doi.org/10.1653/0015-4040(2005)088[0038:BW AELI]2.0.CO;2.

LEMOS, W.P., RAMALHO, F.S., SERRÃO, J.E. and ZANUNCIO, J.C., 2003. Effects of diet on development of Podisus nigrispinus (Dallas) (Het., Pentatomidae), a predator of cotton leafworm. Journal of Applied Entomology, vol. 127, no. 7, pp. 389-395. http://dx.doi.org/10.1046/j.1439-0418.2003.00765.x.

LEMOS, W.P., RAMALHO, F.S., SERRÃO, J.E. and ZANUNCIO, J.C., 2005. Morphology of female reproductive tract of the predator Podisus nigrispinus (Dallas) (Heteroptera: Pentatomidae) fed on different diets. Brazilian Archives of Biology and Technology, vol. 48, no. 1, pp. 129-138. http://dx.doi.org/10.1590/S151689132005000100017.

OLIVEIRA, H.N., ESPINDULA, M.C., DUARTE, M.M., PEREIRA, F.F. and ZANUNCIO, J.C., 2011. Development and reproduction of Podisus nigrispinus (Hemiptera: Pentatomidae) fed with Thyrinteina arnobia (Lepidoptera: Geometridae) reared on guava leaves. Brazilian Archives of Biology and Technology, vol. 54, no. 3, pp. 429-434. http://dx.doi.org/10.1590/S151689132011000300001 .

OLIVEIRA, H.N., PRATISSOLI, D., PEDRUZZI, E.P. and ESPINDULA, M.C., 2004a. Desenvolvimento do predador Podisus nigrispinus alimentado com Spodoptera frugiperda e Tenebrio molitor. Pesquisa Agropecuaria Brasileira, vol. 39, no. 10, pp. 947-951. http://dx.doi.org/10.1590/S0100-204X2004001000001.

OLIVEIRA, H.N., ESPINDULA, M.C., PRATISSOLI, D. and PEDRUZZI, E.P., 2004b. Ganho de peso e comportamento de oviposição de Podisus nigrispinus utilizando lagartas de Spodoptera frugiperda e larvas de Tenebrio molitor como presas. Ciência Rural, vol. 34, no. 6, pp. 1945-1948. http://dx.doi.org/10.1590/ S0103-84782004000600043.

OLIVEIRA, I., ZANUNCIO, J.C., SERRÃO, J.E., ZANUNCIO, T.V., PINON, T.B.M. and FIALHO, M.C.Q., 2005. Effect of female 
weight on reproductive potential of the predator Brontocoris tabidus (Signoret, 1852) (Heteroptera: Pentatomidae). Brazilian Archives of Biology and Technology, vol. 48, no. 2, pp. 295-301. http://dx.doi.org/10.1590/S1516-89132005000200017.

OLIVEIRA, J.E.M., DE BORTOLI, S.A., MIRANDA, J.E., TORRES, J.B. and ZANUNCIO, J.C., 2008. Predação por Podisus nigrispinus (Heteroptera: pentatomidae) sob efeito da densidade de Alabama argillacea (Lepidoptera: Noctuidae) e idades do algodoeiro. Cientifica, vol. 36, no. 1, pp. 1-9.

OLIVEIRA, J.E.M., TORRES, J.B., CARRANO-MOREIRA, A.M. and BARROS, R., 2002. Efeitos das plantas de algodoeiro e do tomateiro, como suplemento alimentar, no desenvolvimento e na reprodução do predador Podisus nigrispinus (Dallas) (Heteroptera: Pentatomidae). Neotropical Entomology, vol. 31, no. 1, pp. 101108. http://dx.doi.org/10.1590/S1519-566X2002000100014.

PELUZIO, R.J.E., 2008. A qualidade da presa afeta o desenvolvimento e a reprodução de Podisus nigrispinus (Heteroptera: Pentatomidae)?. Viçosa: Universidade Federal de Viçosa. 63 p. Dissertação de Mestrado em Fitotecnia.

PIRES, E.M., AZEVEDO, D.O., LIMA, E.R., PELUZIO, R.J.E., SERRÃO, J.E. and ZANUNCIO, J.C., 2009. Desenvolvimento, reprodução e performance predatória do percevejo zoofitófago Podisus distinctus (Hemiptera: Pentatomidae) alimentado com larvas de Musca domestica (Diptera: Muscidae) imobilizadas ou soltas. Revista Brasileira de Biociências, vol. 7, no. 3, pp. 280-284.

SAAVEDRA, J.L., ZANUNCIO, D., ZANUNCIO, T.V. and GUEDES, R.N.C., 1997. Prey captured ability of Podisus nigrispinus (Dallas) (Het., Pentatomidae) reared for successive generations on a meridic diet. Journal of Applied Entomology, vol. 121, no. 1-5, pp. 327-330. http://dx.doi.org/10.1111/j.1439-0418.1997.tb01414.x.

SILVA, R.B., CORRÊA, A.S., DELLA LUCIA, T.M.C., PEREIRA, A.I.A., CRUZ, I. and ZANUNCIO, J.C., 2012. Does the aggressiveness of the prey modify the attack behavior of the predator Supputius cincticeps (Stål) (Hemiptera, Pentatomidae)? Revista Brasileira de Entomologia, vol. 56, no. 2, pp. 244-248. http://dx.doi.org/10.1590/S0085-56262012005000031.

STROHMEYER, H.H., STAMP, N., JARZOMSKI, C.M. and BOWERS, D.M., 1998. Prey species and prey diet affect growth of invertebrate predators. Ecological Entomology, vol. 23, no. 1, pp. 68-79. http://dx.doi.org/10.1046/j.1365-2311.1998.00101.x.

TORRES, J.B., PRATISSOLI, D. and ZANUNCIO, J.C., 1997. Exigências térmicas e potencial de desenvolvimento dos parasitoides Telenomus podisi Ashmead e Trissolcus brochymenae (Ashmead) em ovos do percevejo predador Podisus nigrispinus (Dallas). Anais da Sociedade Entomológica do Brasil, vol. 26, no. 3, pp. 445-453. http://dx.doi.org/10.1590/S0301-80591997000300006.

TORRES, J.B., ZANUNCIO, J.C. and MOURA, M.A., 2006. The predatory stinkbug Podisus nigrispinus: biology, ecology and augmentative releases for lepidoperan larval control in Eucalyptus in Brazil. Biocontrol News and Information, vol. 27, pp. 1-18.

VACARI, A.M. and DE BORTOLI, S.A., 2010. Situação atual e perspectivas da comercialização de agentes de controle biológico no Brasil. In: A.C. BUSOLI, D.J. ANDRADE, J.C. JANINI, C.L. BARBOSA, D.F. FRAGA, L.C. SANTOS, T.O. RAMOS and V.S. PAES, eds. Tópicos em Entomologia Agrícola III. Jaboticabal: Gráfica e Editora Multipress, pp. 91-102.

VACARI, A.M., DE BORTOLI, S.A., GOULART, R.M., VOLPE, H.X.L., OTUKA, A.K. and VEIGA, A.C.P., 2013. Comparison of eggs, larvae, and pupae of Plutella xylostella (Lepidoptera: Plutellidae) as prey for Podisus nigrispinus (Hemiptera: Pentatomidae). Annals of the Entomological Society of America, vol. 106, no. 2, pp. 235-242. http://dx.doi.org/10.1603/AN11190.

VACARI, A.M., OTUKA, A.K. and DE BORTOLI, S.A., 2007. Desenvolvimento de Podisus nigrispinus (Dallas, 1851) (Hemiptera: Pentatomidae) alimentado com lagartas de Diatraea saccharalis (Fabricius, 1794) (Lepidoptera: Crambidae). Arquivos do Instituto Biologico, vol. 74, no. 3, pp. 259-265.

VIVAN, L.M., TORRES, J.B., VEIGA, A.F.S.L. and ZANUNCIO, J.C., 2002. Comportamento de predação e conversão alimentar de Podisus nigrispinus sobre a traça-do-tomateiro. Pesquisa Agropecuaria Brasileira, vol. 37, no. 5, pp. 581-587. http://dx.doi. org/10.1590/S0100-204X2002000500002.

ZANUNCIO, J.C., GUEDES, R.N.C., OLIVEIRA, H.N. and ZANUNCIO, T.V., 2002. Uma década de estudos com percevejos predadores: conquistas e desafios. In: J.R.P. PARRA, P.S.M. BOTELHO, B.S. CORREAA-FERREIRA and J.M.S. BENTO, eds. Controle biológico no Brasil: parasitoides e predadores. São Paulo: Manole, pp.1-13.

ZANUNCIO, J.C., MOLINA-RUGAMA, A.J., SERRÃO, J.E. and PRATISSOLI, D., 2001. Nymphal development and reproduction of Podisus nigrispinus (Heteroptera: Pentatomidae) fed with combinations of Tenebrio molitor (Coleoptera: Tenebrionidae) pupae and Musca domestica (Diptera: Muscidae) larvae. Biocontrol Science and Technology, vol. 11, no. 3, pp. 331-337. http://dx.doi. org/10.1080/09583150120055736.

ZANUNCIO, J.C., TAVARES, W.S., FERNANDES, B.V., WILCKEN, C.F. and ZANUNCIO, T.V., 2014. Production and use of Heteroptera predators for the biological control of Eucaliptus pests in Brazil. Ekoloji, vol. 23, no. 91, pp. 98-104. http://dx.doi. org/10.5053/ekoloji.2014.9112.

ZANUNCIO, T.V., GOMIDES, C.H.F., VARGAS, P.S.R., SOUZA, G.M., RAMALHO, F.S., SERRÃO, J.E. and ZANUNCIO, J.C., 2008. Utilização de mudas de Eucalyptus grandis melhora a criação do predador Brontocoris tabidus (Het.: Pentatomidae) em laboratório. Arquivos do Instituto Biologico, vol. 75, no. 2, pp. 167-172. 